\title{
Terroir - Myth and/or Reality - Outstanding Marketing Idea? A Review
}

\author{
Klaus SCHALLER
}

Hochschule Geisenheim University, Department of Applied Biology, P.O. Box 1154,D-65366Geisenheim, Germany; klaus.schaller@bs-gm.de

\begin{abstract}
In former times the term terroir was connotated negatively. "Le goût du terroir" concerned wines, which could not be sold outside a region, because of quality defects. Later, "terroir products" included agricultural goods produced in specific areas. French scientists developed during the last 3 decennials a scientific base for the system "terroir". All agricultural production systems adhere to a "unité terroir de base (UTB)". An interaction with viticulture, changes it to a "unité terroir viticole (UTV)”. An UTV together with a farm or an AOC creates an identifiable typicity of wines. Other groups of scientists in esp. in Germany tried to find out the influences of meso- and microclima on quality parameters of grapevines as well as soil, nutrients, water and soil heat budget. Mesoclimatic, geomorphological, and soil parameters can explain approximately 60-70\% of the yield formation as well as the sugar accumulation in berries. The unexplained variability adheres to human skills, soil management, harvesting techniques etc. Following the production chain from bunches to wine increasing interventions occur: juice extraction systems, spontaneous or controlled fermentation with defined yeast strains. Temperature control, filtration systems will exert an influence on the final wine quality. In contrast to the limited intervention during production of grapes, wine making exceed by far the first mentioned and terroir turns to a "quantité negligeable" in the final wine. Nonetheless, on the consumers' side terroir is still in discussion. Producers have to respect these movements and have to develop strategies how to incorporate those ideas in their production schemes and their marketing activities.
\end{abstract}

Keywords: origin, regional products, production systems, socio-economic aspects soils Abbreviations: AOC: Appelation d'Origine Contrôlé; AVA: American Viticultural Area

\section{Introduction}

It seems that the term "terroir" is omnipresent, especially in viticulture and enology but it penetrates also specific areas of agricultural and horticultural production. Particularly distribution and marketing channels are affected. It appears that products of specific esteem may be categorized with "terroir" origin. Exceptionally the term is found on wine labels from abroad and home, information flyers of wine estates, magazines and product informations. At the latest during a lunch in a restaurant one is confronted with it when the sommelier makes his wine offers.

Such terms which are used for different opportunities and concepts require different methods of approach in order to get a comprehensive overview of this system, which developed during the last decades or possibly centuries.

A first glimpse may cause for non-professionals that terroir has to do something with vine growing because in that commercial field it is mostly used. In a more superficial way it is connected with soil or in a wider sense with regional provenience. One can state that a multitude of meanings exist with the inherent danger that this mixture gives everyone the possibility to agree with its own belief and personal understanding which will end up in a real confusion of ideas (Pauli, 2016; Goode, 2017)

Bearing these risks in mind it seems necessary to search, if possible, for potential scientific bases. These findings should be the baseline for the information, which will be afterwards transferred to the public through the diverse medias. It is compulsory that the validity of the facts is as high as possible. Finally, the expectation should be that the evolving discussions will have an impact on the society as a whole and specific groups which are susceptible to new developments and ideas in the sector of nutrition, lifestyle, agricultural production and its goods.

The current status of the terroir discussion is more or less dominated by diverse mainstream media e.g. "Decanter" (www.timeincuk.com/brands/decanter/), but can also be found to a lesser amount in scientific journals e.g. "Journal de la Science de la Vigne et du Vin" resp. "OENO one 
(http://oeno-one.eu), “American Journal of Enology and Viticulture" (www.ajevonline.org/), "Australian Journal of Grape and Wine Research" (http://onlinelibrary.wiley. com/journal/10.1111/(ISSN)1755-0238), national journals e.g. "Der Deutsche Weinbau" (www.der-deutscheweinbau.de), "Der Winzer" (www.der-winzer.at), "Revue des Oenologues" (www.oeno.tm.fr) etc. Described are mainly local aspects like a specific region and its corresponding wines. What is missing is a comprehensive understanding of the terroir system itself as a scientific based theory and its implications on grower and producers, the consumer and the society. An up-to-date compilation with a strong relation to science-based facts was currently published by Hoppmann et al. (2017).

\section{Terroir: Its Roots and Early Development}

In former times the term was characterized negatively. "Le goût du terroir" concerned wines, which could not be sold outside a region, because of quality defects. Later, the meaning turned and "terroir products" included agricultural goods produced in specific areas (Martin, 2002).

Meaning and sense of the word terroir has no linguistic equivalent in the English, German or other languages. Beginning with 90 s of the last century the term got trendy in the field of viticulture and winemaking. The reason may be the search for a good balance between the rapid technological progress, which is currently noticed in our highly developed societies and the traditional concepts of biology. These movements as "back to nature", care for the environment have surely fostered studies about terroir and the valorization of "terroir products".

In the field of science a multitude of actors from different viticulture countries e.g. Argentine, Brazil, Chile, France, Germany, Portugal, Spain and USA formed the term terroir in its current meaning.

\section{Terroir: Etymology}

Terroir has two meanings: 1. "territorium" (lat.) which resulted in territorium or terroir; it corresponds with a specific area conquered by the Roman army and ruled by the military authorities and under the supervision of the Roman law. 2. During the medieval times the term "produit de terroir" (fr.) was used in order to characterize an agricultural product as natural and original, coming from a distinct place and not to be found elsewhere.

The mix of both etymological roots in combination with its historical connotation is without any doubt the character of the French "Terroir", which since then is also part of the international wine vocabulary.

In 2010 the OIV (International Wine Office) approved the resolution OIV/VITI 333 concerning "Terroir", defining:

"Vitivinicultural "terroir" is a concept which refers to an area in which collective knowledge of the interaction between the identifiable physical and biological environment and applied vitivinicultural practices develops, providing distinctive characteristics for the products originating from this area. "Terroir" includes specific soil, topography, climate, landscape characteristics and biodiversity features".
Some years earlier in 1990 also the UN passed a more general definition of the term "terroir": terroir refers to areas whose cultural-historical values are the result of complex and long-term relations between cultural, social, ecological and economic characteristics.

\section{Terroir: Tool to characterize vineyards and wines}

Regardless of lingual differences French scientists from universities and research units tried to develop during the last 3 decennials a scientific base for the system "terroir". For all agricultural production systems an "unité terroir de base (UTB)" was created. (Base unit for plant production). Is there an interaction with viticulture, then it changes to a "unité terroir viticole (UTV)" (Fig. 1). An UTV together with a farm or an AOC creates an identifiable typicity of wines).

In general this proposal can be seen as a "base unit" for plant production. Important is the interaction between meso-climate - covering the complete growing cycle - and the soil.

If such a system interacts with grapevines and its diverse cultural practices (trellis system, leaf area, productivity, hydrologic factors a.s.f.) it will change to a "viticulture terroir unit" (UTV). Such a UTV in combination with a farm or another classification unit (AOC, AVA) shall be responsible for a wine's typicity. However, in such a system the man plays a key role. He is responsible for interventions which are necessary for a successful production e.g. pruning, soil preparation, plant protection, irrigation, fertilization, harvesting etc. Human determinants dictate the actions, which interact with the UTB's environment and in a wider sense with the society. The nexus with the typicity is really obvious. This proposed terroir system operates on a high level of aggregation, whereas some important facts are left in the dark.

\section{Terroir: a rational dimension}

Every agricultural activity is aware of the relationship between the natural fertility of agricultural areas and the potential yields of different crops. This is a more or less practical know-how of farmers, gardeners and viticulturist.

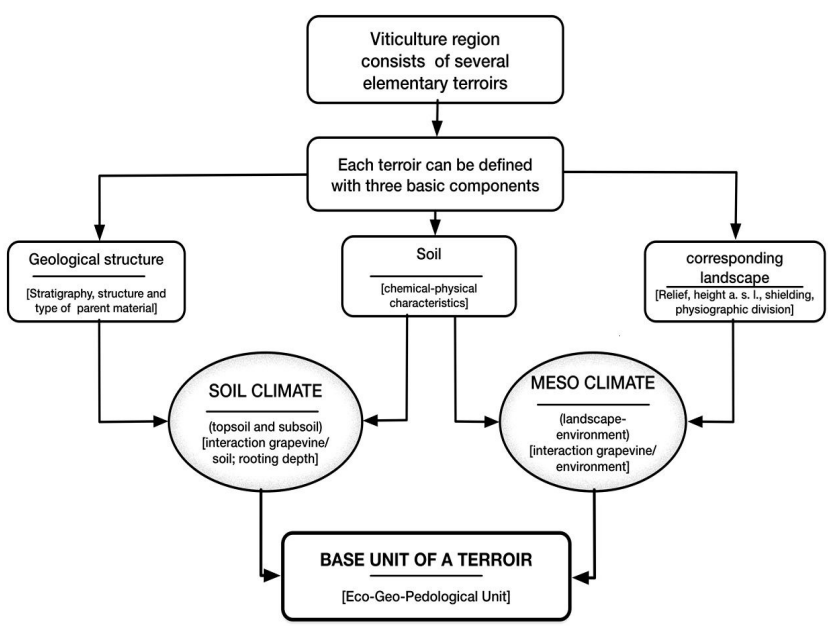

Fig. 1. Structure and inner relationships in a terroir unit (UTB) 
334

Based on this knowledge basis in Germany a scheme was introduced for the evaluation of soils used for agricultural production (Rothkegel and Herzog, 1935; Bodenkundliche Kartieranleitung, 2005). Essential elements are soil type, geological origin and degree of development. For viticultural soils in addition $\mathrm{CaCO}_{3}$ content, plant available water and soil heat conditions are used for further characterization. Those findings are also published in the internet e.g. http://weinbaustandort.hessen.de/mapapps/resources/app a/weinbaustandort/index.htm?land=de.

Such schemes exist nearly in every country, and unsurprisingly date back till ancient times. Already Columella in his book "De Re Rustica Libri Duodecim" described a classification for selection of grapevine plantations (Columella, 1981). Pliny documented similar facts for the area of Falerne (Plinius, 1964).

Early types of zonation following geographical points of view are found in the Tokaj region (1700), Tuscany (1716), and Douro (1756), which exist until now. In contrary, the system of Bordeaux (1855) is diametrically oriented, because it classifies the producers according their market values.

Agricultural activities during the development of mankind led to an enormous treasure of knowledge, which included also the knowledge of classification. For example, during the nineties of the last century an old classification map of the Prussian tax authorities dating back to 1885 was found; it contained all the vineyards of the Rheingau region whose owners achieved highest incomes from wine selling. Nearly all the vineyards are congruent with the results of a research project which classified vineyards according their meteorological and soil characteristics in order to evaluate "high quality" producing vineyards (Hoppmann, 2004).

The "terroir" concept emerged at the beginning of the 20th century in connection with classification work of Kuhnholtz-Lordat (1963). Basis was a law from 1905, which claimed specific standards for agricultural products, especially geographical provenience and production standards. The work was finished in the nineteen-thirties and finally led into the AOC-system.

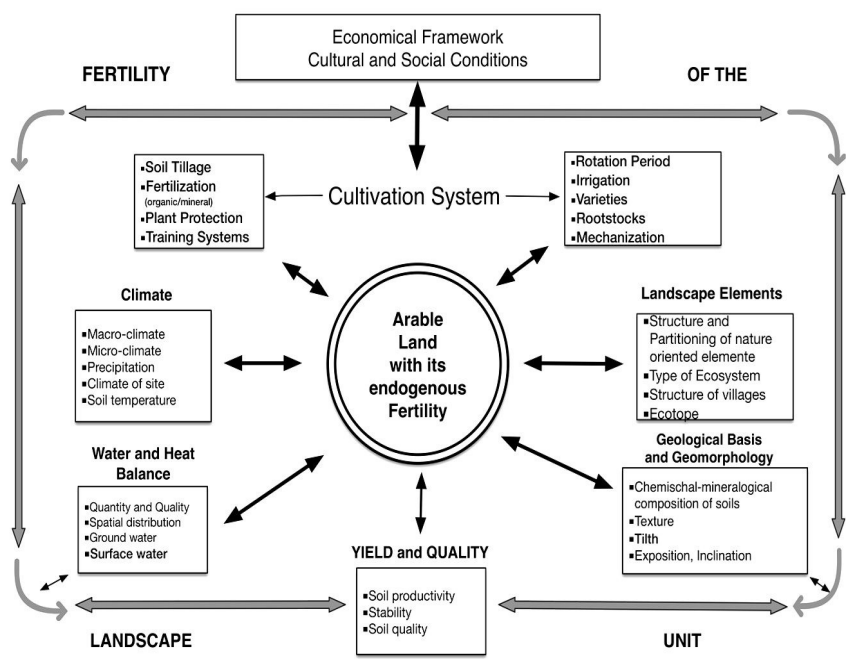

Fig. 2. Theoretical model for viticultural production sites together with invariant and modifiable variables (acc. to Dabbert, 1994; modified by the author)

\section{Terroir: geographic-geomorphological unit}

All proposals to characterize terroir units use the geographical classification of natural landscapes. An example is given in Fig. 2.

The present status of a landscape is the result of a sequence of geological processes (heavings and tectonic subsidences, abrasions, weathering and displacement), which is now the basis for production. Fig. 2 demonstrates how a viticultural production system may be incorporated in a given landscape. As can be noted the potential fertility of an production area is determined by 4 units: climate, water and heat balance, landscape elements, geological origin and geomorphological elements. They dictate what can be possibly produced without any intervention. Human activity can change the physical and chemical features of the soils through fertilizers (organic and mineral) and soil tillage (mechanical and/or biological). However, a landscape in use does not stay static; the acting man will shape "his" landscape with help of different crops, cultivation systems, rotations, degree of mechanization.

In the case of grape growing the viticulturist will determine the exact time for picking in order to harvest an outstanding quality. Yield and quality will change when climate, water and heat balance will fluctuate or change permanently.

\section{Terroir: soil factors}

In almost all publications either scientific or popular the soil is conceded an utmost influence. More than 10 international conferences about terroir where held in different countries since 1996. Following all the commentaries and advices given from viticulturists, wine enthusiasts, journalists and wine merchants it is the soil, which is responsible for the differentiation of wines.

From scientific point of view one can state, the soil is a substrate for the grapevine where it can establish and anchor the root system. During the complete life cycle (ø 20-40 years) it can feed itself with water, nutrients and possibly other active ingredients. In general, soil is a physicochemical reactor which is active during the whole growing season and which is driven by rainfall (=water) and solar radiation (=thermal energy). In contrast to some other popular believes the bedrock material does not contribute anything to these activities. It is important for the landscape forms but has no relevance for the grapevine and its performance. Nevertheless, exists a lot of contributions of geologists to the terroir and its development (Burns, 2012; Bussaca and Meinert, 2003; Hancock, 2005; Hugget, 2005; Wilson, 1999).

An important role for a successful growth of grapevines plays soil physical properties, in particular aeration, soil heat transfer and as a main factor the water capacity, which is in close connection with soil texture.

It is the merit of Seguin $(1970,1986)$ with his research work about the before mentioned factors on berry quality in the region of Haute-Medoc. In 1991, Van Leeuwen made similar tests in Saint-Emillion and confirmed the findings. The research group about Morlat et al. $(1981,1989)$ and Asselin et al. (1992) extended the site characteristics for soil depth and introduced the term "water sustainability". These 
findings are valid for viticulture areas. Currently comprehensive maps exist for plant available water. They can be used for irrigation management in vineyards.

There is a real lack of information about nutrient supply of grapevines and the terroir aspect. One reason why nutrients shall not play a role for the forming of the terroir is their considerable fluctuation during a growing season. And in addition they can also introduced from outside into the system. This is contradictory to the terroir idea because it is supposed that it has to be static.

In a 10 years series of experiments in the Rheingau area in 112 test plots yields, must density and acidity were annually recorded. It was possible to study the influence of climatic and site factors on the grapevine's performance (Hoppmann, 1987; Hoppmann and Schaller, 1981, 1997, 1999).

Calculating the must density with help of a multiple regression analysis it is possible to estimate $30 \%$ of the variability with two variables, namely $\mathrm{P}$ and $\mathrm{K}$ content in the subsoil (Fig. 3).

If the factor combination is increased for site characteristic - height a.s.l., solar radiation income, exposition and inclination, plant available water - roughly $70 \%$ of the must densities variability can be explained. Examining individual years of this series one can see that specific sites have advantages e.g. higher plant available water reserves in dry years or disadvantages in high rainfall periods (Hoppmann and Schaller, 1981).

Nitrogen as most important nutrient for plants is nearly not mentioned in terroir literature. Absolutely astounding, because without this nutrient no proper viticulture is possible, particularly with regard to the existing high consumer demands on wine quality.

For the viticulturist is it a difficult task to fulfill the grapevine's requirement for nitrogen as can be seen in Fig. 4.

The grapevine has a varying demand for nitrogen during the annual growing cycle (Fig. 4). It can be seen that at the early beginning of growth the uptake is negligible; some grams per day and hectare. During the phase 5-6 leaves

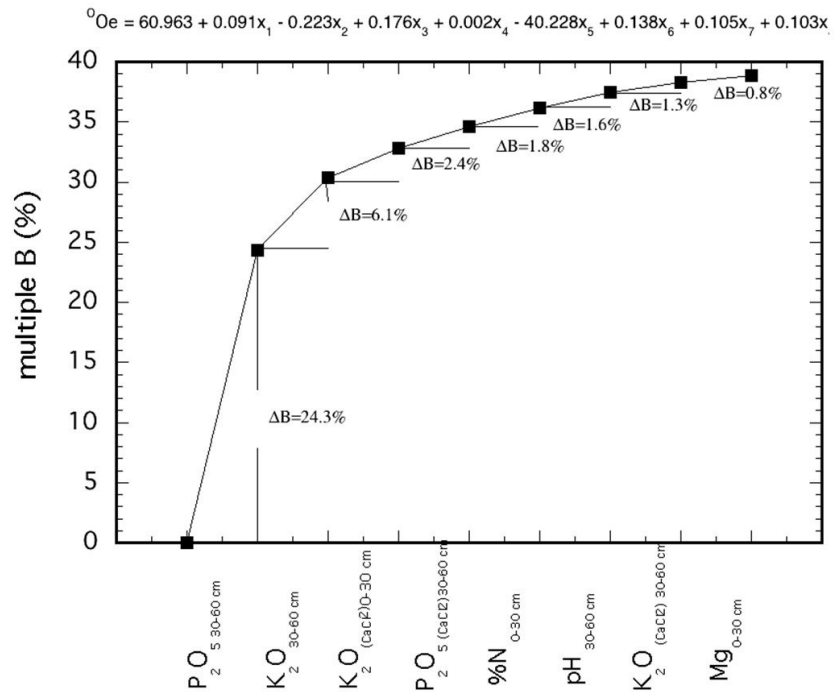

Fig. 3. Estimation of must densities $\left({ }^{\circ} \mathrm{Oe}\right)$ with a multiple regression from soil properties of 112 test sites and 10 years (Hoppmann and Schaller, 1997). [Multiple B $=\mathrm{R}^{2} \times 100$ ] developed until bloom $\mathrm{N}$ demand increases up to 500-800 g $\mathrm{N} /$ ha and day. After bloom it increases dramatically to nearly $2000 \mathrm{~g} \mathrm{~N} / \mathrm{ha}$ and day. There is also a smaller peak after veraison; probably it is extraordinary important for the accumulation of amino acids in the berries, which are important for the yeast nutrition during the fermentation process.

The soil has to offer these amounts of $\mathrm{N}$ every year and at the right time for a high quality must. If this is not possible the final wine quality will probably suffer.

Nitrate is the preferred ion, which is taken up by grapevines and metabolized after its reduction in leaves (Schaller, 1984). Nitrate formation in soils is a complex process, because a bundle of exogenous environmental and endogenous soil factors trigger nitrification, nitrate build up and movement in the rooted solum of vineyards (Berthold, 1991).

A synopsis of several long lasting field experiments dealing with soil tillage, green cover (green manuring and permanent grass) and the related $\mathrm{NO}_{3}$ formation in cool climate vineyards resulted the following outcomes (Fig 5, ad). Comparing nitrate contents in tilled (Fig. 5a) and grassed (Fig. 5c) vineyards striking differences can be noticed. In tilled soils the main factor for nitrate formation is the soil's carbon content and term W, which consists of rainfall $\mathrm{x}$ sunshine hours. Both are determined by summing up the measured values one decade before soil testing. Together with the soil water content roughly $50 \%$ of the variability of soil nitrate in the upper $20 \mathrm{~cm}$ layer can be explained. In contrast, in grassed vineyards (Fig. 5c) nitrate build up is mainly determined by the average soil temperature in $50 \mathrm{~cm}$ soil depth $(B=37 \%)$ and to a lesser extent by rainfall, measured 1 decade before soil testing.

Including into the calculations the available nitrate in the layer 20-40 cm depth (Fig $5 \mathrm{~b}$, d), it can be seen that $54 \%$ of $\mathrm{NO}_{3}$ variability is determined by the $\mathrm{NO}_{3}$ content in the second soil layer followed by sunshine hours (7.9\%) and the carbon content $(2.5 \%)$. In the grassed system the main variable is still the temperature in $20 \mathrm{~cm}$ soil depth

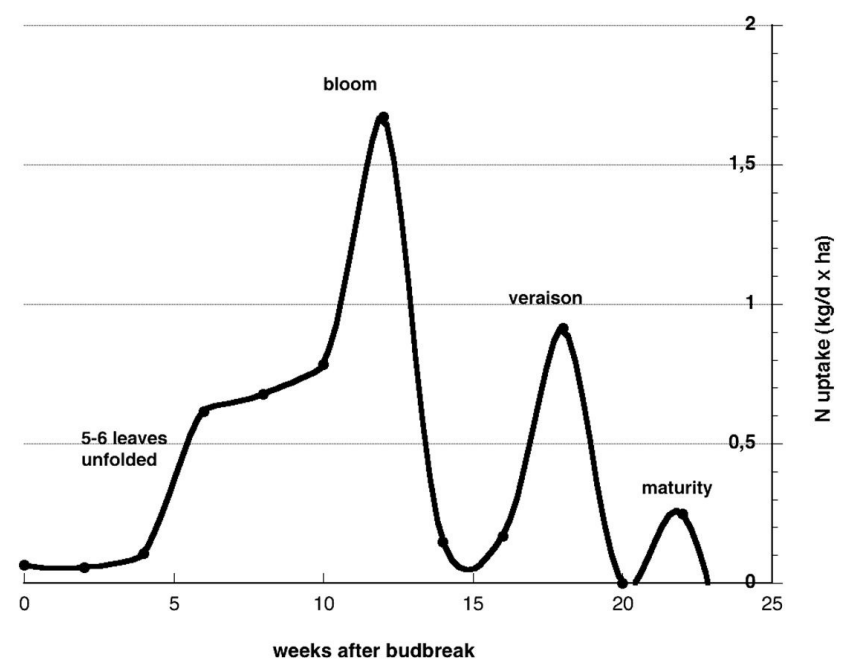

Fig. 4. Daily $\mathrm{N}$-uptake of Riesling grapes during a growing cycle in $\mathrm{kg} \mathrm{N} /$ ha and day (after Löhnertz, 1988, modified by Schaller) 

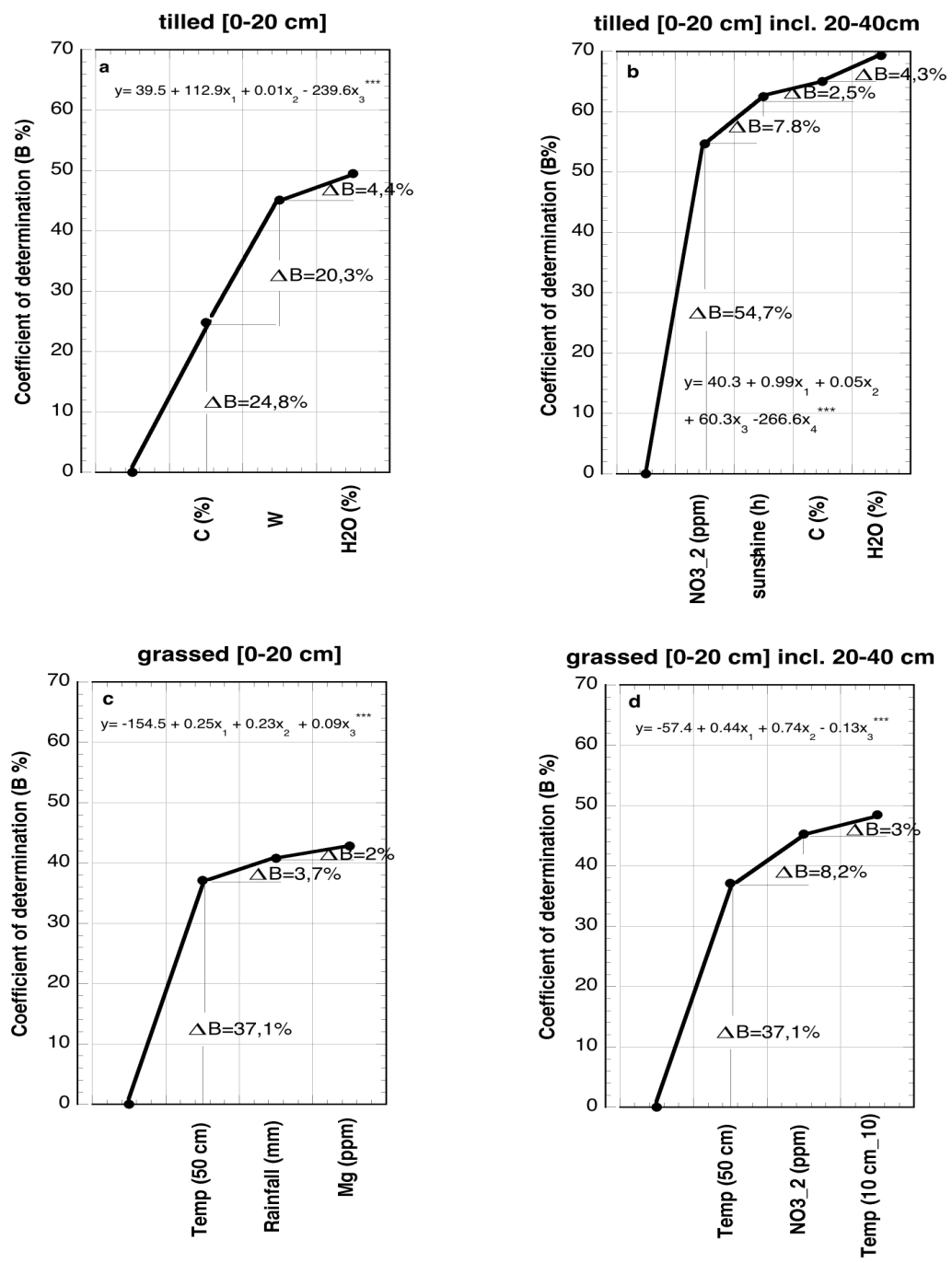

Fig. 5. Nitrate formation in vineyard soils according to differing soil management systems

(37\%). In second place is the $\mathrm{NO}_{3}$ content in the second soil layer (8\%) (Grimm, 1986; Guthier, 1982; Husar, 1983; Stark, 1991).

The presented results allow the conclusion that soil management systems may exert a strong influence on the nitrate dynamic in soils and directly have an impact on the grapevine's growth and development. In other words human activities may cover the static terroir by dynamic changes of the nutrient supply. Finally the influence of the acting viticulturist is substantial and may shift the expected wine quality beyond the borders of a given "terroir".

If the nutrient demand of the grapevines and the nutrient supply of the soil cannot be synchronized in a proper way, impacts may be expected on the synthesis of different plant compounds which may influence the final wine quality negatively.

\section{Terroir: plant physiological aspects}

Every plant is part of its own ecosystem and may be influenced by all exogenous factors. The direction of the influence may be positive i.e. distinct physiological activities are increased and in inverse way some factors may reduce specific synthetic pathways.
Research results about the influence of exogenous factors (light, water, trellising, pruning, soil management, canopy architecture a.s.f.) is legion and cannot discussed here in detail. Particularly with regard to the new world countries and their entrance in wine research the publications increased exponentially (American Journal of

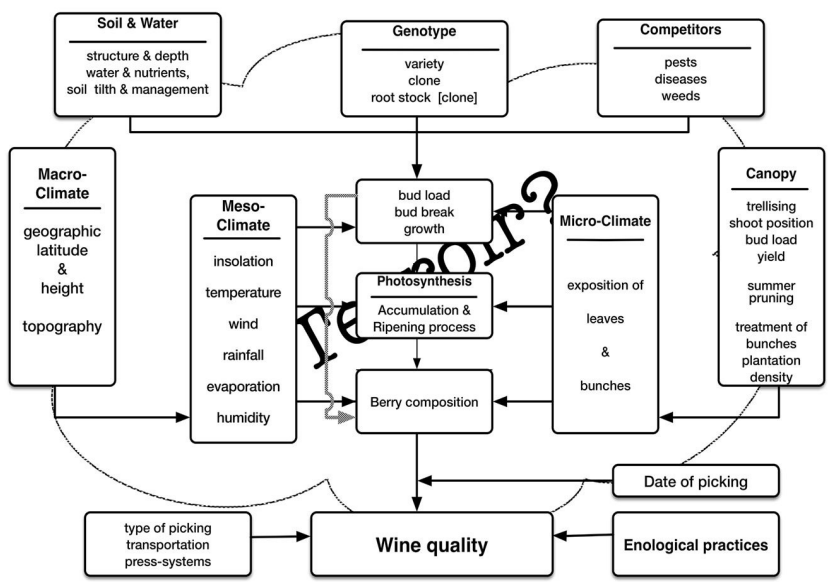

Fig. 6. Terroir with special consideration of crop production factors (after Smart and Robinson, 1991) 
Enology and Viticulture; Australian Journal of Grape and Wine Research).

The perspective about the role of grapevines in a terroir is given in Fig. 6.

This method of approach excludes the elements "landscape", and "geological and geomorphological elements" and replaces them by macro-climate, geographical latitude and altitude as well as the topography. All are responsible for the local climate. As can be seen the grapevine takes the centre stage which can be physiologically stimulated by diverse actions of canopy management (Ryona et al., 2008; Wang et al., 2014), trellising (Šklje et al., 2016), varieties and clonal material (Charlton et al., 2010; Jogiaah et al., 2010; Šuklje et al., 2016) fertilization (Jackson and Lombard, 1993; Stockert et al., 2013), irrigation (Escalona et al., 1999; Berdeja et al., 2014) and changes of the micro climate (Deloire and Hunter, 2005; Ryona et al., 2008; Greer and Weedon, 2013).

These factor bundles can be actively manipulated by the viticulturist i.e. the consequence will be that the original terroir with its effects will take a background seat. With all these effects in mind it is hard to believe that the terroir has a distinctive effect on the final product.

A small detail of the plant's nitrogen metabolism may illustrate this: the grapevine has to take up nitrogen either from the soil or under specific condition through the leaves. If it is not possible during periods of highest demands (see Fig. 4) to supply enough $\mathrm{N}$ from the soil, the plant accumulates great amounts of carbohydrates assumed that there is further enough $\mathrm{CO}_{2}$, water and light. Normally the carbohydrate skeletons are needed for synthesis of amino acids. Nonetheless, the plant cannot get rid of this carbohydrates and therefore a metabolic pathway is used to synthesize from phenyalanine cinnamic acid, which is a primary source for "plant phenolics" (Razal et al., 1996; Singh et al., 1998) (Fig. 7).

Environmental stressors induce different reactions of grapevines: UV-B leads to the formation of quercitin, kaempferol und hydroxycinnamon acid (Alenius et al.,
1995), higher temperature changes anthocyanin formation (Kliewer and Torres, 1972; Spayd et al., 2002). Direct insolation of berries increases soluble phenolics (Crippen and Morrison, 1986; Bergqvist et al., 2001). Biotic stress fosters the synthesis of resveratrol (Jeandet et al., 1995; Landrault et al., 2002). Deloire et al. (2004) explain the relationship between stress, berry size and accumulation of anthocyanins. There exist also interactions between nitrogen, potassium and phenolics (Kliewer, 1977; Delgado et al., 2004). Ca applicated on leaves induces PAL-activity and the synthesis of phenolics (Ruiz et al., 2003).

In the light of these facts it is implausible that the terroir is a dominating factor for the quality development in grapevines.

\section{Terroir: winemaking processes}

Normal viticulture has a human component: it is mostly combined with physical stress in order to wrest the nature the fruits. In contrast winemaking or enology has the image to be only techniques or technology. In some circles it is discussed that viticulture is the soul and enology is ratio. Is that true?

Normally during a winemaking process the enologist is involved in the complete quality management beginning with the grapes' ripening process, time of picking, transport, avoiding mechanical stress on bunches, protection against oxidation etc.

Juice extraction is a central process during white wine making. It seems to be a simple step! How it can change the composition of the final must is demonstrated in Fig. 8 .

Both, ammonium and arginine are very important compounds for a perfect fermentation.

It can be seen that the presence of stems increases the amount of N-compounds; probably the flow of must out of the press-cake is improved, because a strong compaction is avoided. In addition, longer skin contact reduces extractable ammonium and arginine. Striking is also the influence of the press power.

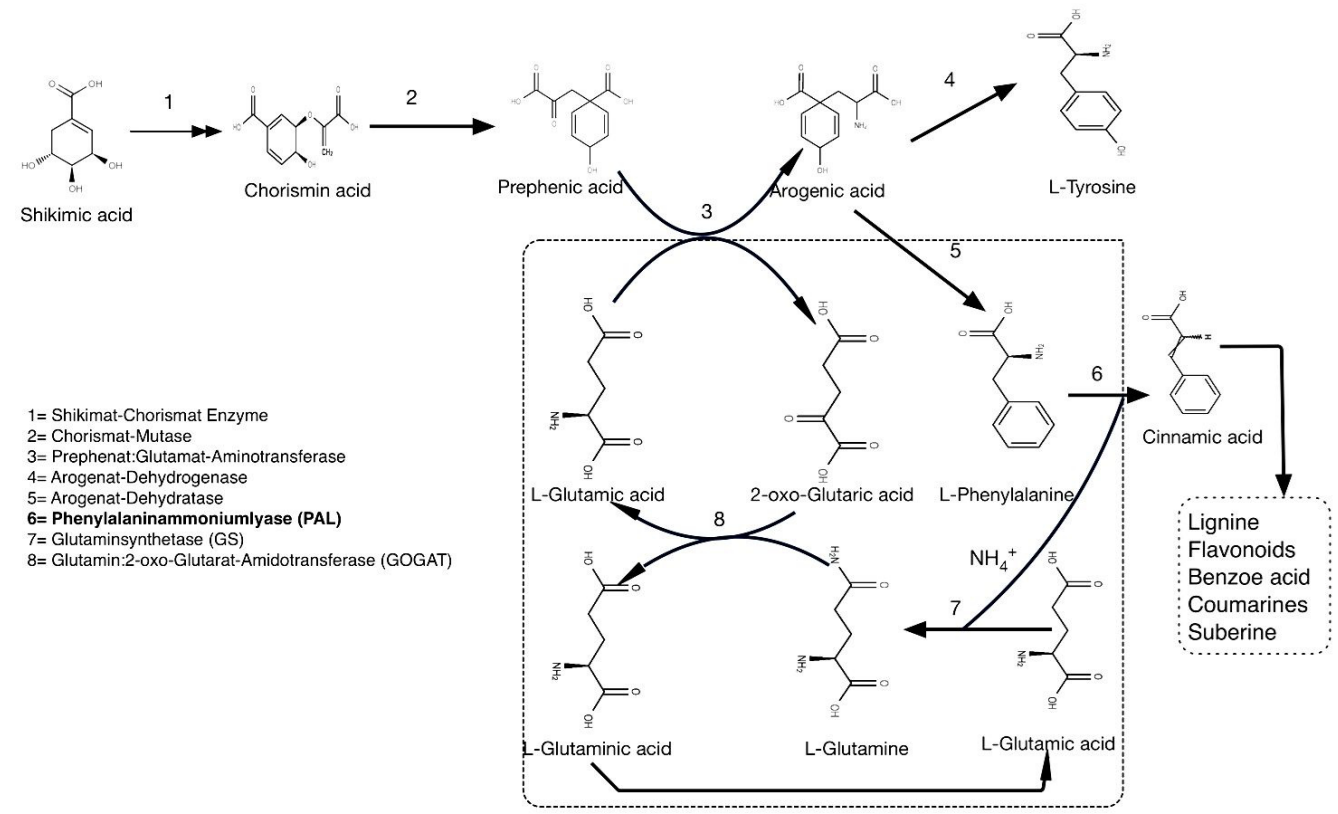

Fig. 7. Synthesis of phenolic compounds in plants during $\mathrm{N}$ deficiency periods by activation of the phenyl propanoid pathway 

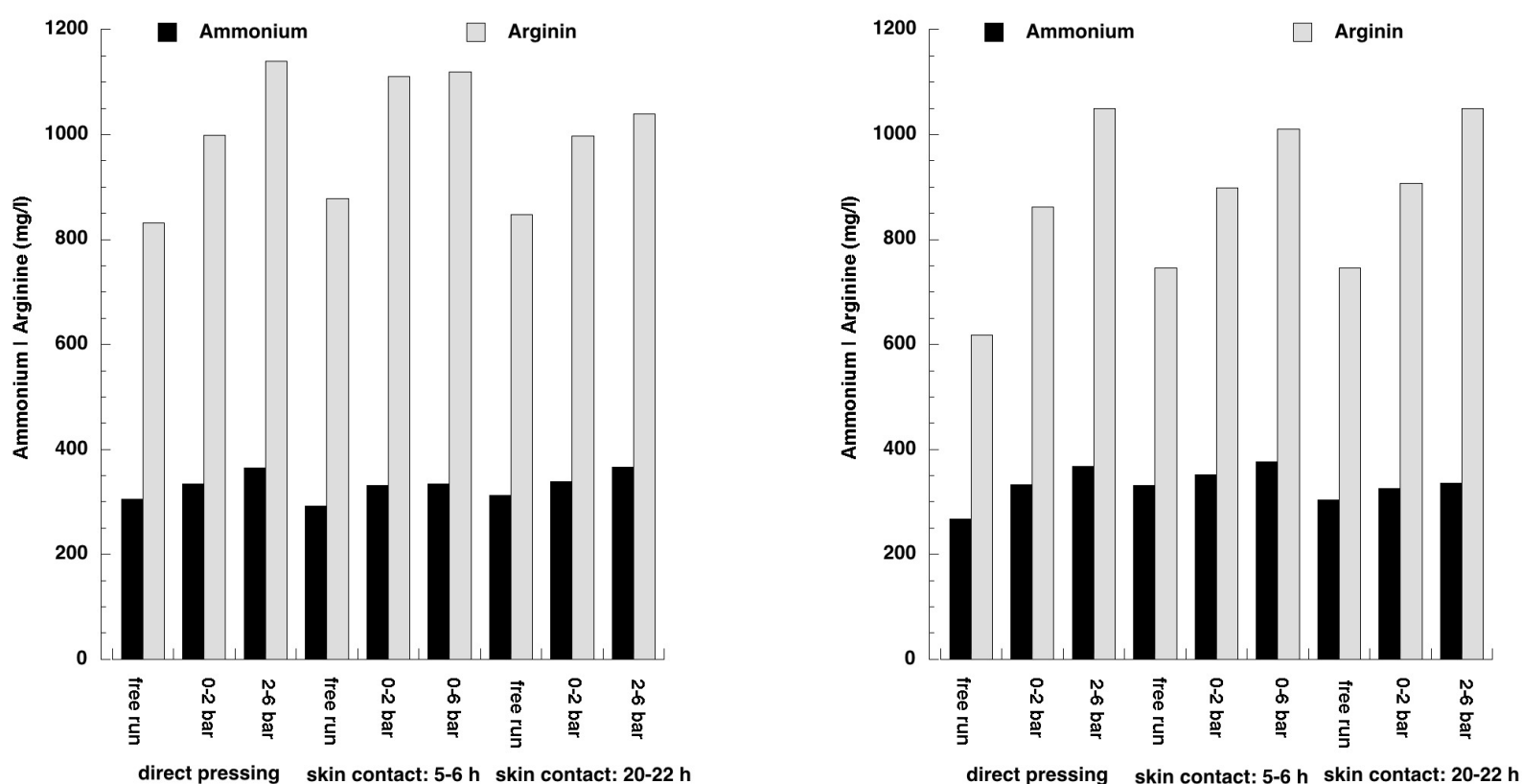

Fig. 8. Contents of ammonium and arginine in musts from 'Riesling' by direct pressing, after 5-6 h and 20-22 h skin contact and three press-fractions. Mash with stem (left), de-stemmed mash (right) (Mengler, 1985)

Alone, this small example demonstrates how farreaching may be the consequences using the "best" juice extraction program. During red wine production such decisions are quite more important because much more compounds are affected e.g. the complete aroma spectrum.

Another black box which is more and more opened, is the fermentation process. Yeasts may influence taste, flavor and after taste sensations (Rauhut et al., 1996; Rauhut, 2009; Schuller et al., 2012). The yeast flora of a production site (terroir?) does not consequently shape the final wine (Gerhards et al., 2015; Rousseaux et al., 2017).

Praetorius (2011) stated: "The results of the last years demonstrate, that the microbiology of musts and wines is no more an auxiliary science for the terroir, it is an autonomous science in the field of enology. The findings will probably revolutionize, may be in one or two decades the total wine science".

Storage, fining, oxygenation as well as storing in barriques are interventions which alter the product away from the terroir. Finally the wood used for the barrels may transfer a specific imprint into the wine (Seegmüller, 2014).

The product wine shall not primarily create an association with a specific landscape because it is a natural stimulant, which will trigger emotions through its structure, aromas and taste: to feel at ease with a fine dish, desert and accompanying persons.

\section{Terroir: economical aspects}

In a short review of the global situation of viticulture one can see that the market is dominated by five big players: Spain (1.021 Mio ha), China (0.799 Mio ha), France (0.792 Mio ha), Italy (0.690 Mio ha) and Turkey (0.502 Mio ha), i.e. $50 \%$ of the global acreage is cultivated in these five countries.

The global wine production amounts to $280 \mathrm{Mio} \mathrm{hL}$ and is since years constant. The big fives are France (46.6
Mio hL), Italy (47.7 Mio hL), Spain (41.6 Mio hL), USA (22.3 Mio hL) and Argentine (15.1 Mio hL). The actual consumption is $\approx 240$ Mio hL, i.e. 40 Mio $\mathrm{hL}$ rove around the global markets.

Roughly five countries consume $50 \%$ of the worldwide production: USA (13\%), France (12\%), Italy (9\%), Germany (8\%) and China (7\%).

All these figures and statistics can be researched under http://www.oiv.int./oiv/cms/index and Euromonitor (2008).

Does these figures have any meaning on the different zoning systems worldwide?

During the last three decades the global wine markets changed remarkably. Little by little the markets shifted from a producer driven system to a consumer driven market, i.e. only those products are in demand, which can fulfill the inherent characteristics which are in the consumer's interest. If the terroir system or the American AVA (American Viticultural Area) or other rules of reference are so important for the consumer that he will give them his personal preference is currently a matter of question.

\section{Terroir: an international systems?}

Since the GATT agreement (General Agreement on Tariffs and Trade) in 1994 permanent discussions arose between EU and USA and they did not slow down, in contrary. Especially, one part concerning intellectual properties and which covers "Geographical Indications" (GI). Such GI are often used in the field of Wines and Spirits as labels of "Origin". In the TRIPS regulations exist article 23 (TRIPS, 2016). It can be used for cheese, meat and other products. Here, a certain conflict potential may arise between GI and AOC. Probably, both system will be brought to congruence in the future and a worldwide system may develop (Bérard and Marchenay, 2001; Goodman and Watts, 1994; Moschini et al., 2008). 


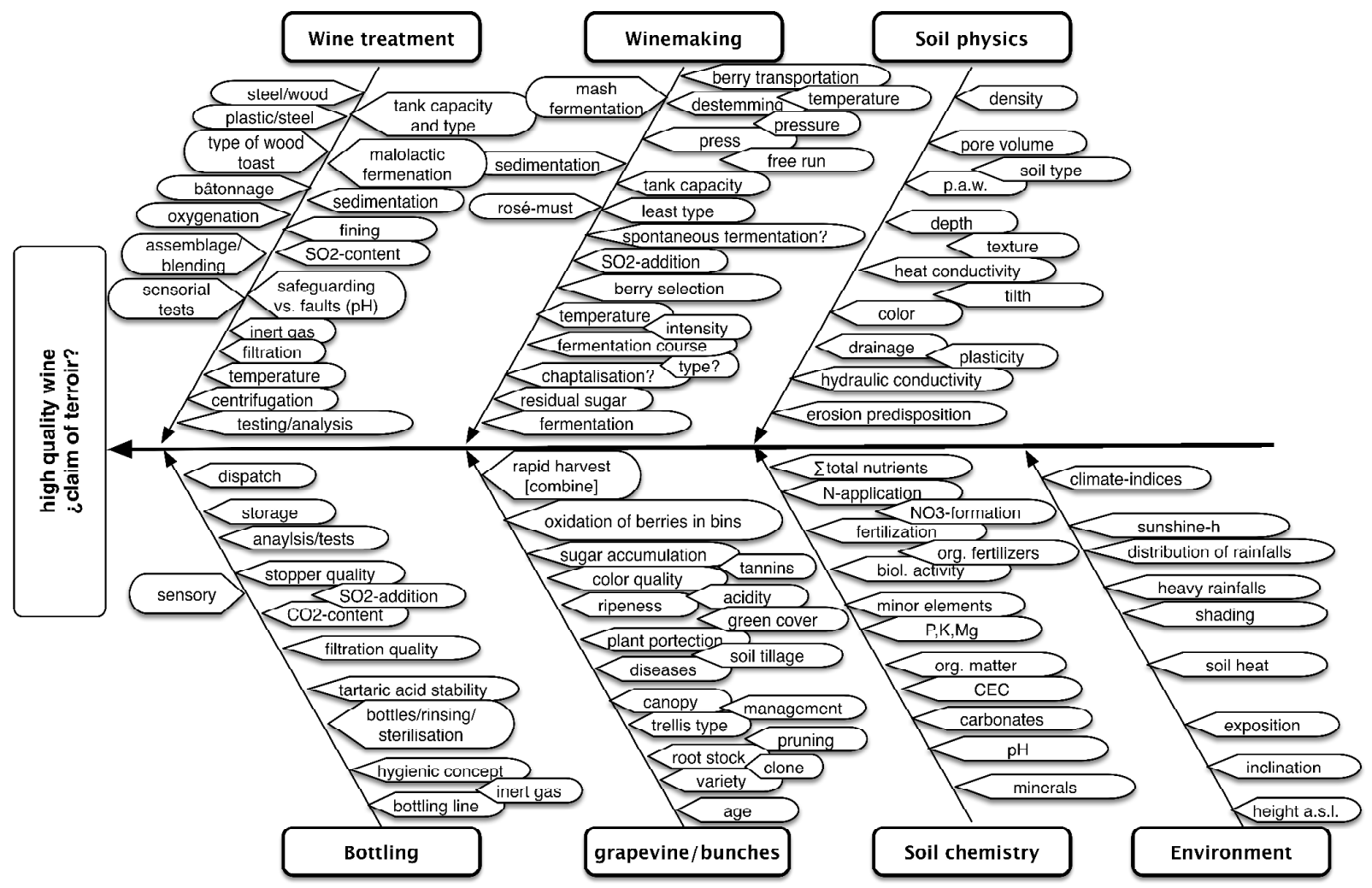

Fig. 9. Production chain of grapevine production and winemaking

\section{Terroir: socio-cultural aspects}

Besides the technical sphere the term "terroir" has also a social dimension, because man is also part of a landscape, is mentally formed by the complete milieu, develops an specific life-style. Important is also the regionality and the type of populous areas.

These five factors form the humans and create a terroir (Beck, 1982). With regard to social aspects the term terroir is broadened and versatile: fear in view of globalization and massification and the wish for better social structures.

In a consequence out of such ideas in 1989 "Slow Food" was founded in Italy. Followers of this movement have all the same ambition for regionality and terroir. Their repertoire comprises also a re-evaluation of viticultural and agricultural products.

All products have an emotional and nostalgic connotation, combining tradition, idealization of the past and a disposition for hospitality and fine culinary art. May be, a part of utopia is built. The quality of the former products were by no means that those we can buy today. It is a form of nostalgia.

\section{Terroir: the future}

The ideas and presentation of the terroir as a whole and the attempt to describe it as scientifically based and verifiable factum until relevant social aspects show that simple solutions are not available in order to have always a right answer.

Some facts can be measured objectively such as the behavior of the plant in the environment as well as reactions of the soil.
The complete production chain from the field to the bottle on the other hand produces a complete different view (Fig. 9).

One can see, at the beginning act some fixed environmental, soil physical and chemical factors, which can only restrictive manipulated. Passing into viticulture and finally enology the number of possible interventions increase disproportionately high. It can be stated the more the move is towards the wine ready for consumption there more moves the imprint of the production site in the backseat.

Newly, economists have begun to do research about terroir questions. They formulated that terroir is a social construct (Gergaud and Ginsburgh, 2008; Josling, 2006). From this point of view it is not more than an ,idea" which the protagonists have. Some others argue terroir is only a protectionist barrier of nationalistic administrations for agriculture and harsh wine critic who judge the quality are parasites of this market (Combris, et al., 1997; Gergaud and Ginsburgh, 2008; Shapin, 2005).

An intensive debate began about misinterpretations of the terroir and the AOC-System (Addor and Grazioli, 2002; Charlier and Ngo, 2007; Handler, 2006; Josling, 2006; Moschini et al., 2008). The term "Terroir - Quality“ seems to have difficulties to be fit into a definition or it cannot strictly enough defined.

After much deliberation and rating it can be stated that the term terroir especially in the wine scene has partially developed to a surrogate towards a desire for nature and nativeness. According to our lifestyle facts have to have formulated strictly and well communicated. Everybody has to note that the wine taste is "hip". Going this way, one avoids the complexity which the wine holds and which 
340

cannot be described during a fast and short enjoyment. Terroir means on the other hand to accept that during a comprehensive production chain "demands for the gustatory sense" will arise, for which also an enologist is highly responsible.

\section{Conclusions}

Terroir as a concept in agricultural as well as in food production is currently reaching a turning point from a pure product driven system which has its roots in a movement referring to nature and natural products towards a market respectively marketing driven system. A more or less scientifically based fundament ensured the survival for nearly one century. The upcoming globalization coupled with an un-restraint exchange of goods and services altered the denotation of the term terroir. Research revealed that there are some assumptions, which could not be verified, esp. the fact of an imprint of a landscape in a product. In the future it has to be looked for a sound symbiosis between of verified terroir knowledge and fair marketing activities, which can give the idea and the products a new push.

\section{References}

Addor F, Grazioli A (2002). Geographical indications beyond wines and spirits. The Journal of World Intellectual Property 5(6):865-897.

Alenius CM, Vogelman TC, Bornman JF (1995). A three-dimensional representation of the relationships between penetration of U.V. - B radiation and U.V.- screening pigments in leaves of Brassica napus. New Phytologist 13:297-302.

Asselin C, Pages J, Morlat R(1992). Typologie sensorielle du Cabernet Franc et influence du terroir. Utilisation de méthodes statistiques multidimensionelles. International Journal of Vine and Wine Sciences 26:129-154.

AVA (2016). American Viticultural Area (AVA). Retrieved 2017 April 2 from http://www.ttb.gov./winr/avashtml.

Beck H (1982). Große Geographen. Pioniere, Außenseiter, Gelehrte. Dietrich ReimerVerlag, Berlin.

Bérad L, Beucherie O, Fauvet M, Philippe M, Monticelli C (2001). Indication gégraphique protégée. Critères de Zonage. Chambre Régionale d'Agriculture Rhône-Alpes, Lyon, France.

Bérad L, Marchenay P (2001). Le sens de la durée: Ancrage historique des "Produits de Terroir". In: Autrement No 194, Vives Campagnes: Le Patrimoine Rural, Project de Sociétépp 191-216.

Berdeja M, Hilbert G, Dai ZW, Lafontaine M, Stoll M, Schultz HR, Delrot $S$ (2014). Effect of water stress and rootstock genotype on Pinot Noir berry composition. Australian Journal of Grape and Wine Research 20(3):409-421.

Bergqvist J, Dokoozlian N, Ebisuda N (2001). Sunlight exposure and temperature effects on berry growth and composition of Cabernet Sauvignon and Grenache in the Central San Joaquin Valley of California. American Journal of Enology and Viticulture 52(1):1-7.

Berthold G (1991). Untersuchungen zur N-Dynamik weinbaulich genutzter Flächen unter besonderer Berücksichtigung der Bewirtschaftungsform [Investigations into the $\mathrm{N}$ dynamic of vineyard soils with special consideration of soil management systems]. $\mathrm{PhD}$ thesis University Gießen.
Bodenkundliche Kartieranleitung (2005). Bodenkundliche Kartieranleitung KA5 [Manual of soil mapping 5th Ed] Schweizerbart Science Publishers Stuttgart.

Burns S (2012). The importance of soil and geology in tasting terroir with a case history from the Willamette Valley, Oregon. In: Dougherty FH (Ed). The Geography of Wine: Regions, Terroir and Techniques. SpringerDordrecht-Heidelberg-London-New York.

Bussaca AJ, Meinert LD (2003). Wine and geology - The terroir of Washington State. In: Swanson TW. Western Cordillera and Adjacent Areas. Geological Society of America Field Guide 4:69-85.

Charlier C, Ngo MA (2007). An analysis of the European Communities: Protection of trademarks and geographical indications for agricultural products and foodstuffs dispute. The Journal of World Intellectual Property 10(3-4):171-186.

Charlton AJ, Wrobel MS, Stanimirova I, Daszykowski M, Grundy HH, Walczak B (2010). Multivariate discrimination of wines with respect to their grape varieties and vintages. European Food Research and Technology 231(5):733-743.

Columella LIM (1981).Zwölf Bücher über Landwirtschaft (De Re Rustica Libri Duodecim). Artemis VerlagMünchen

Combris P, Lecocq S, Visser M (1997). Estimation of a hedonic price equation for Bordeaux wine: does quality matter? Economic Journal 107:390-402

Crippen DD, Morrison JC (1986). The effects of sun exposure on the compositional development of Cabernet Sauvignon berries. American Journal of Enology and Viticulture 37(4):235-242

Dabbert S (1994). Ökonomik der Bodenfruchtbarkeit [Economy of Soil Fertility] Verlag Ulmer,Stuttgart.

Delgado MRP, del Alamo M, Gonzales MR (2004). Changes in the phenolic composition of grape berries during ripening in relation to vineyard nitrogen and potassium fertilization rates. Journal of the Science of Food and Agriculture 84:623-630.

Deloire A, Carbonneau A, Wang ZP, Ojeda H (2004). Vine and water - a short review. Journal International des Sciences de la Vigne et du Vin 38:1-13.

Deloire A, Hunter JJ (2005). Microclimat des grappes et maturation du raisin. Progrès Agricole et Viticole 122:151-156.

Escalona JM, Floxas J, Schultz HR, Medrano H (1999). Effect of moderate irrigation on aroma potential and other markers of grape quality. Acta Horticulturae 493:261-267.

Euromonitor (2008). The World Market for Wine (www.euromonitor.com).

GATT (1986). The General Agreement on Tariffs and Trades, Geneva pp 1-105.(https://www.wto.org/english/doc_e/legal_e/gatt47_e.pdf).

Gergaud O, Ginsburgh V (2008). Natural endowments, production technologies and the quality of wines in Bordeaux. Does terroir matter? TheEconomic Journal 118:F142-F157.

Gerhards D, Büchl N, Wenning M, Scherer S, von Wallbrunn Ch (2015). Terroir or yeast? - Application of FTIR spectroscopy and molecular methods for strain typing of yeasts. BIO Web of Conferences 5, 02001 DOI: $10.1051 /$ bioconf/20150502001.

Goode J (2017). Mechanism of terroir. Retrieved 2017 March 01 from http://wineanorak.com/mechanism_terroirl.htm. 
Goodman D, Watts M (1994). Reconfiguring the rural or fording the divide? Capitalist restructuring and the global agro-food system. Journal of PeasantStudies 22(1):149.

Greer HD, Weedon MM (2013). The impact of high temperature on Vitis vinifera L. cv. Semillon grapevine performance and berry ripening. Frontiers in Plant Science 4:491.

Grimm L (1986). Untersuchungen über die $\mathrm{N}_{\min }$-Methode und deren Anwendbarkeit in weinbaulich genutzten Böden [Investigation about the $\mathrm{N}_{\min }$ method and its suitability in viticultural used soils] Diploma Thesis. University Geisenheim.

Guthier O (1982). Einfluß verschiedener Bodenpflegesysteme auf die Nährstoffdynamik in weinbaulich genutzten Böden [Influence of differing soil management systems on the nutrient dynamic in viticultural soils]. Diploma Thesis University Geisenheim.

Hancock JM (2005). Geology of wine. In: Selley RC, Cocks LRM, Plimer IR (Eds). The Encyclopaedia of Geology Vol III. Elsevier, Amsterdam pp 85-90.

Handler M (2006). The WTO Geographical Indications Dispute. Modern Law Review 69:70-80.

Hoppman D (1999). Die Karte des potentiellen Mostgewichtes fur das Weinbaugebiet Rheingau als objektive Grundlage zur Charakterisierung de Weinlagen. In: Proceedings of the 24 th World Congress for Grapes and Wine pp 176-183.

Hoppmann D (1987). Der Einfluss von Jahreswitterung und Standort auf die Mostgewichte der Rebsorten Riesling und Mueller-Thurgau (Vitis vinifera L.). Agrarmeteorologischer Beitrag zur Standortbeurteilung im Weinbau [Influence of weather conditions and production site on must density of the varieties Riesling and Mueller-Thurgau. Agrarmeteorological contribution for site evaluation in viticulture]. $\mathrm{PhD}$ Thesis University Gießen.

Hoppmann D, Schaller K (1981). Der Einfluss verschiedener Standortfaktoren aufQualität und Quantität der Reben (2. Mitteilung). [Influence of different production site factors on quality and quantity of grapevines] Wein-Wissenschaf36:299-319.

Hoppmann D, Schaller K (1997). Characterization of vineyard sites for quality production using meterological and soil chemical and physical data. Les Terroirs Viticoles. 1er Colloque International, Angers.

Hoppmann D, Schaller K (1999). Characterization of Vineyard sites for quality wine production - German experiences. Territorio \& Vino. La zonazione strumento di conoscenza per laqualità. Siena.

Hoppmann D, Schaller K, Stoll M (2017). Terroir - Wetter, Klima, Boden [Terroir-Weather, Climate, Soil].Eugen Ulmer,Stuttgart.

Hugget JM (2005). Geology and wine: a review. Proceedings of the Geologists' Association 117:239-247.

Husar K (1983). Untersuchungen über die Auswirkungen der N-Düngung nach der $\mathrm{N}_{\text {min }}$-Methode auf die Rebe [Investiagtion into $\mathrm{N}$ fertilization of grapevines and the $\mathrm{N}_{\min }$ method]. Diploma Thesis, University Geisenheim.

Jackson DI, Lombard PB (1993). Environmental and Management Practices Affecting Grape Composition and Wine Quality - A Review. American Journal of Enology and Viticulture 44:409-430.

Jeandet P, Bessis R, Sbaghi M, Meunier P (1995). Production of the phytoalexin resveratrol by grapes as a response to botrytis attack under natural conditions. Journal of Phytopahthology 143:135-139.

Jogiaah S, Oulkar DP, Banerjee K, Ravendran P, Rokade NP (2010). Amino acid profile of Thompson Seedless grapes grafted on different rootstocks at various stages of berry development. International Journal of Fruit Science 10:323-340.

Josling T (2006). The war on Terroir: Geographical indications as a transatlantic trade conflict. Journal of Agricultural Economics 57:337363.

Kliewer WM, Torres RE (1972). Effect of controlled day and night temperatures on grape coloration. American Journal of Enology and Viticulture 23:71-77.

Kuhnholtz-Lordat G (1963). La genèse des appellations d'origine des vins. Buguet-Comptour, Mâcon.

Landrault N, Larcade F, Delauney JC, Castagnino C, Vercauteren J, Merillon JM, ... Teissedre PI (2002). Levels of stilbene oligomers and astilbin in French varietal wines and in grapes during noble rot development. Journal of Agriculture and Food Chemistry 50:20462052.

Löhnertz O (1988). Untersuchungen zum zeitlichen Verlauf der Nährstoffaufnahme bei Vitis vinifera L. cv. Riesling [Investigations about the time course of nutrient uptake in Vitis vinifera L. cv. Riesling] Geisenheimer Berichte Bd 1 .

Martin JC (2002). Triste "gout de terroir" dans l'histoire du vin. Revue Française del'Oenologie 196:37-39.

Mengler H (1985). Einfluss unterschiedlicher Maischebehandlungen und Pressdrücke aufden Nitratgehalt in Mosten [Influence of different mash treatments and press power on the nitrate contents in musts]. Thesis, Faculty of Viticulture and Enology, University Geisenheim.

Morlat R (1989). Le terroir viticole: contribution à l'étude de sa caractérisation et son influence sur les vins; application aux vignobles rouges de la Moyenne Vallée de la Loire. $\mathrm{PhD}$ thesis, Université Bordeaux II, Bordeaux.

Morlat R, Puissant C, Asselin C, Leon H and Remque M (1981). Quelques aspects de l'influence du milieu édaphique sur l'enracinement de la vigne, consequences sur la qualité du vin. Bulletin de l'Association Française d'EtudeduSol 2:125-145.

Moschini GC, Menapace L, Pick D (2008). Geographical indications and the competitive provision of quality in agricultural markets. American Journal of Agricultural Economics 90(3):794-812.

Pauli E (2016). Goût de Terroir. Retrieved 2016 October 10 from http://www.ernestopauli.ch/wein/Weinbau/Terroir.htm.

Plinius dÄ (1964). Naturalis Historia. Fruchttragende Bäume. 2 Bde. Artemis Winkler Akademie VerlagStuttgart.

Praetorius S (2011). Plenary lecture on the occasion of the inaugural meeting. University Geisenheim.

RauhutD (2009). Usage and Formation ofSulphur Compounds. In: König $\mathrm{H}$ et al. (Eds). Biology of Microorganisms on Grapes, in Must and Wine.Springer Verlag Berlin Heidelberg.

Rauhut D, Kürbel H, Dittrich HH, Grossmann M (1996). Properties and differences of commercial yeast strains with respect to their formation of sulfur compounds. Wein-Wissenschaft 51(3-4):187-192.

Razal R, Ellis S, Singh S, Lewis NG, Towers GHN (1996). Nitrogen Recyclingin Phenylpropanoid Metabolism. Phytochemistry 41:31-35. 
342

Rothkegel W, HerzogH (1935). Das Bodenschätzungsgesetz [The Law for the German Soil Inventory]. Heymann Berlin.

Rousseaux S, Grangeteau C, Gerhard D, v. Wallbrunn Ch, Alexandre H, Guiloux-Benstier M (2017). Origin des levures Saccharomyces et nonSaccharomyces présentes dans le moût: vignoble ou cuverie?. Revue des Oenologues 162:28-31.

RuizJM, Rivero BM, Lopez-Cantareo I, Romero L(2003). Role ofCa2+ in the metabolism of phenolic compounds in tobacco leaves (Nicotiana tabacum L.). Plant Growth Regulation 41:173-177.

Ryona I, Pan BS, Intrigliolo S, Lakso A, Sacks GL (2008). Effect of cluster light exposure on 3-isobutyl-2-methoxypyrazine accumulation and degradation patterns in red wine grapes (Vitis vinifera L. cv. Cabernet Sauvignon). Journal of Agriculture and Food Chemistry 56:1083810846.

Schaller K (1984). Investigations on nitrate reductase activity in grapevines. Mitteilungen Klosterneuburg 34:235-240.

Schuller D, Cardoso F, Sousa S, Gomes P, Gomes AC, Santos MA, Casal M (2012). Genetic diversity and population structure of Saccharomyces cerevisiae strains isolated from different grape varieties and winemaking regions. PLoSOne7(2):e32507.

Seegmüller S (2014). Wie beeinflußt das Holz-Terroir den Wein? [Does the terroir of the wood influence the wine]. Der Deutsche Weinbau 16/17:46-49.

Seguin G (1970). Les sols de vignobles du Haute-Medoc. Influence sur l'alimentation en eau en cas de la vigne et sur la maturation du raisin. $\mathrm{PhD}$ thesis, University of Bordeaux II, Bordeaux.

Seguin G (1986). "Terroirs" and pedology of wine growing. Experientia (Basel) 42:861-872.

Shapin S (2005). Hedonic Fruit Bombs. London Review of Books 27:3032.

Singh S, Lewis NG, Towers GN (1998). Nitrogen recycling during phenylpropanoid metabolism in sweet potato tubers. Journal of Plant Physiology 153(3-4):316-323.
Smart RE, Robinson MD (1991). Sunlight into Wine. A Handbook for Winegrape Canopy Management. Winetitles, Adelaide.

Spayd SE, Tarara JM, Mee DL, Ferguson JC (2002). Separation of sunlight and temperature effects on the composition of Vitis vinifera cv. Merlot berries. American Journal of Enology and Viticulture 53:171-182.

Stark W (1991). Der Einfluß des Mulchsystems und N-Düngung auf den Nitrat- und Wassergehalt des Bodens, sowie aufErtrag, Qualität undNGehalt der Rebe [Influence of mulching systems and N fertilization into nitrate and water content of vineyard soils as well as on yield, quality and N content ofgrapes]. Diploma thesis, University Geisenheim.

Stockert CM, Bisson LF, Adams DO, Smart DR (2013). Nitrogen status and fermentation dynamics for Merlot on two rootstocks. American Journal of Enology and Viticulture 64:195-202.

Šuklje K, Antalick G, Buica A, Langlois J, Coetzee ZA, Gouot J, ... Deloire A (2016). Clonal differences and impact of defoliation on Sauvignon blanc (Vitis vinifera L.) wines: a chemical and sensory investigation. Journal of the Science of Food and Agriculture 96(3):915-926.

TRIPS (2016). Annex 1c, Artikel 22, 1 und 23. Retrieved 2016 January 1 from https://www.wto.org/english/tratop_e/trips_e/t_agm3_e.htm.

van Leeuwen CP (1991). Le vignoble de Saint Emillion: répartition des sols et fonctionnement hydrique, incidence sur le comportement de la vigne et la maturation du raisin. $\mathrm{PhD}$ thesis University of Bordeaux II, Bordeaux.

Wang L, Harada J, Endo Y, Hisamoto M, Saito F, Okuda T (2014). Diurnal changes of amino acid concentrations in Riesling and Chardonnay grape juices and possible role of sunlight. American Journal of Enology and Viticulture 65:435-442.

Wilson JE (1999). Terroir. Schlüssel zum Wein [Terroir. Key to the Wine]. Hallwag Verlag, Bern-Stuttgart. 